\title{
The use of zeolite-based geopolymers as adsorbent for copper removal from aqueous media
}

Haci Baykara ${ }^{1,2^{*}}$, Maria de Lourdes Mendoza Solorzano ${ }^{3}$, Jose Javier Delgado

Echeverria $^{3}$, Mauricio H. Cornejo ${ }^{1,2}$, Clotario V. Tapia-Bastidas ${ }^{1}$

${ }^{1}$ Facultad de Ingeniería Mecánica y Ciencias de la Producción, Escuela Superior Politécnica del Litoral, ESPOL, Campus Gustavo Galindo Km 30.5 Vía Perimetral, Guayaquil, Ecuador

${ }^{2}$ Center of Nanotechnology Research and Development (CIDNA), Escuela Superior Politécnica del Litoral, ESPOL, Campus Gustavo Galindo Km 30.5 Vía Perimetral, Guayaquil, Ecuador

${ }^{3}$ Departamento Ciencias Químicas y Ambientales, Facultad de Ciencias Naturales y Matemáticas, Escuela Superior Politécnica de Litoral, ESPOL, Campus Gustavo Galindo km 30.5 Vía Perimetral, Guayaquil, Ecuador

\section{Abstract}

Copper has been proven to have hazardous effects on human beings depending on its concentration levels. Recently, there has been a growing interest in developing geopolymers using local industrial minerals and by-products. However, research on the adsorption of heavy metals by geopolymer based on mordenite-rich tuffs is still limited. In the present study, an Ecuadorian zeolite-based geopolymer's removal capacity on copper ions in aqueous solutions, varying concentration, and contact time was tested. Kinetic models were developed using pseudo-first-order, pseudo-secondorder, and the Elovich model. The adsorption data, using $\mathrm{Cu}^{2+}$ concentrations from 20 to $160 \mathrm{ppm}$, at $25^{\circ} \mathrm{C}$ were described by the Langmuir and Freundlich isotherms and assessed by the linear coefficient of determination $\left(R^{2}\right)$, resulting in the best fit for the Langmuir model. The attained adsorption capacity of $52.63 \mathrm{mg} \mathrm{g}^{-1}$ demonstrates the low-cost geopolymer's effectiveness for this study and its competitiveness compared with other studies.

Keywords: Geopolymer; adsorption; zeolites; wastewater; kinetics; adsorption isotherms.

\footnotetext{
${ }^{*}$ Corresponding author: H.Baykara, hbaykara@espol.edu.ec
} 


\section{Introduction}

Copper, a heavy metal, has long and short-term adverse effects on human health, especially on the gastrointestinal system and the environment in general (National Research Council (US) Committe on Copper in Drinking Water, 2000; Taylor et al., 2020). Copper is widely used in the photographic and electronic industries, power plants in general, and consequently, is commonly found in wastewater. Therefore, its availability beyond a critical threshold in the environment is undoubtedly dangerous for human beings and animals. So, it is crucial to control and remove a significant amount of copper from water (Duan et al., 2016).

Adsorption processes are a feasible alternative due to their flexibility in design and operation, and, in many cases, they generate high-quality treated effluents. Several factors such as the size of the hydrated ions, free energy of hydration, and metal ions activity may be responsible for this selectivity of adsorption (Cheng et al., 2012). On the other hand, a geopolymer is an amorphous material generated by the reaction of an aluminum silicate with an alkali hydroxide, usually $\mathrm{NaOH}$ (Baykara et al., 2017; Arnoult et al., 2018). Recently, there has been a growing interest in developing geopolymers using local industrial minerals and by-products for immobilization of dangerous elements as a possible solution to struggle against heavy metal contamination (Barrie et al., 2015; Andrejkovicoá et al., 2016; Cristelo et al., 2020; Obenaus-Emler et al., 2020).

The removal of copper on metakaolin, fly ash, and zeolite-based geopolymers and other inorganic solids have been demonstrated in several studies (Wang et al., 2007; Yousef et al., 2009; Cheng et al., 2012; Sen Gupta and Bhattacharyya, 2014; AlHarahsheh et al., 2015). Fixed bed trials were carried out to assess modified silica capability to selectively remove $\mathrm{Cu}^{2+}$ from a multi-component solution ( $\mathrm{Kim}$ and $\mathrm{Yi}$, 2000; Sthiannopkao and Sreesai, 2009), by using boiler mud and ash to remove copper by adsorption and precipitation processes from metal refining water.

There has been little investigation done on the adsorption of heavy metals by geopolymer based on mordenite-rich tuffs to the best of our knowledge. In this case, the use of natural raw materials in geopolymer synthesis has been challenging, mainly due to their heterogeneity. 
The purpose of this study is to evaluate the capacity of the Ecuadorian zeolite-based geopolymer for the removal of copper ions in aqueous solutions by varying concentrations and contact times.

\section{Materials and methods}

\section{Preparation of the geopolymer}

The Ecuadorian zeolite was pulverized in a ball mill to collect the fraction less than 60 $\mu \mathrm{m}$. Subsequently, it was added to an activating solution composed of $\mathrm{Na}_{2} \mathrm{SiO}_{3}$ (Merck, density $1.35 \mathrm{~g} \mathrm{~mL}^{-1}$ at $20^{\circ} \mathrm{C}, \mathrm{Na}_{2} \mathrm{O}$ 7.5-8.5\%, and $\mathrm{SiO}_{2} 25.5-28.5 \%$ ) and $10 \mathrm{M} \mathrm{NaOH}$ (Merck-Millipore, $99 \%$ purity) at a ratio of 2.5:1. The solution was mixed with zeolite at a ratio of $0.45 \mathrm{~mL} \mathrm{~g}^{-1}$ and stirred for 2 minutes. The resulting mixture was poured in 5 $\times 5 \times 5 \mathrm{~cm}$ wooden molds, covered with plastic bags, and placed in an oven at $60{ }^{\circ} \mathrm{C}$ for 24 hours. Finally, the cubes were left at room temperature $\left(26 \pm 2{ }^{\circ} \mathrm{C}\right)$ for 9,16 , and 27 days before the compressive strength testing.

\section{Characterization of the geopolymer}

For structural stability, compressive strength tests were performed to assess the zeolite-based geopolymer's strength, using the ASTM C109 / C109 M-16a standard method and a SHIMADZU UTM-600KN, Universal Testing Machine. Prior testing, geopolymer blocks labeled as B3, C3, and D3, were sanded, sized $(46.86 \mathrm{~mm} \times$ $50.52 \mathrm{~mm} \times 46.24 \mathrm{~mm}, 48.30 \mathrm{~mm} \times 50.60 \mathrm{~mm} \times 46.80 \mathrm{~mm}$ and $51.78 \mathrm{~mm} \times 47.45 \mathrm{~mm} \times$ $45.62 \mathrm{~mm}$, respectively), and analyzed for compression tests at 10,17 and 28 curing days. The tensile rupture strength values were $40.3875,52.1888$, and $66.0000 \mathrm{kN}$ for B3, C3, and D3, respectively. Geopolymer blocks were placed in an oven at $60^{\circ} \mathrm{C}$ for one day and then cured at room temperature $\left(26 \pm 2^{\circ} \mathrm{C}\right)$ for an additional 9,16 , and 27 days before compressive strength tests were carried out.

For quantitative X-ray diffraction analysis, a PANalytical X'Pert PRO equipment was used at $30 \mathrm{~mA}, 45 \mathrm{kV}$, and angular measurement range of 0-80 (20Theta). According to the study reported by Baykara et al. (Baykara et al., 2017). The peaks of the crystalline structures present in the samples were determined with an X'Per High Score Plus Software. 
The elemental composition of the zeolite-based geopolymer samples was analyzed utilizing Dispersive Energy Spectrophotometry using an FEI-Inspect S Scanning Electron Microscope. For this purpose, the samples were crushed, and a small portion was taken on a plate with a graphite sheet. The gold coating was applied for the highresolution micrographs of geopolymer samples.

For the Fourier-Transform-Infrared Spectroscopy (FTIR) test, $2 \mathrm{mg}$ of the zeolite-based geopolymer samples (previously dried at $60^{\circ} \mathrm{C}$ for 6 hours) were mixed and homogenized with $200 \mathrm{mg} \mathrm{KBr}$, in an agate mortar. A pressure of $9 \mathrm{MPa}$ was applied for 7 minutes for the pellet preparation. A Spectrum 100 Perkin Elmer spectrophotometer was used for the testing, with an atmosphere of UHP nitrogen, with a spectrum range between 4000 and $400 \mathrm{~cm}^{-1}$ and a resolution of $1 \mathrm{~cm}^{-1}$.

For the thermogravimetric and the differential scanning calorimetry analysis, $10.0 \pm 0.5$ $\mathrm{mg}$ of the geopolymer sample was weighed in a previously red hot burned capsule. The equipment used was a thermogravimetric calorimeter TA SDT Q600, with a nitrogen flow of $100 \mathrm{~mL} \mathrm{~min}^{-1}$ and a ramp of $10.00^{\circ} \mathrm{C} \mathrm{min}^{-1}$ in a range between 25 up to $1000^{\circ} \mathrm{C}$. The data were interpreted using an Advantage TA Universal Analysis 4.5A software.

\section{Adsorption experiments}

For the adsorption experiments, the geopolymer samples were grounded to a particle size of less than $60 \mu \mathrm{m}$. The tests were carried out in batch mode. For that, the synthesized geopolymer was dried for 2 hours at $100^{\circ} \mathrm{C}$ and weighed before each adsorption experiment. On the other hand, standard solutions of $100 \mathrm{ppm}$ and $250 \mathrm{ppm}$ of $\mathrm{Cu}^{2+}$ were prepared for the batch mode experiments, and for the determination of the adsorption isotherm, the $\mathrm{Cu}^{2+}$ concentration varied between $20 \mathrm{ppm}$ and $160 \mathrm{ppm}$ at a temperature of $25^{\circ} \mathrm{C}$. First, $50 \mathrm{~mL}$ of copper solution was poured into glass flasks previously immersed in a water bath to stabilize the temperature. Subsequently, $0.1 \mathrm{~g}$ of geopolymer was added to each flask, gently homogenized, and allowed to stand still for 2 hours. The solution was immediately vacuum filtered using $0.45 \mu \mathrm{m}$ filter paper and analyzed by flame atomic absorption spectroscopy (FAAS). The quantity of the copper adsorbed onto the geopolymer samples has been determined quantitatively using the atomic absorption spectrometer (Thermo Scientific ICE 3000 Series). 
For the kinetic analysis, flasks containing $100 \mathrm{ppm}$ of $\mathrm{Cu}^{2+}$ in aqueous solution and adsorbent dose of $2 \mathrm{~g} \mathrm{~L}^{-1}$ were placed in a water bath at $25^{\circ} \mathrm{C}$. The flasks were vacuum filtered using $0.45 \mu \mathrm{m}$ filter paper at a specified time and analyzed by FAAS.

The Effective removal of methylene blue from water using phosphoric acid based geopolymers: synthesis, characterizations and adsorption studies capacity $\mathrm{q}\left(\mathrm{mg} \mathrm{g}^{-1}\right)$ and the efficiency were determined with equations 1 and 2 , respectively:

$$
\begin{aligned}
& q=\frac{\left(C_{o}-C_{e}\right) * V}{m} \\
& E=\frac{\left(C_{o}-C_{e}\right)}{C_{o}} * 100 \%
\end{aligned}
$$

Where $\mathrm{C}_{0}\left(\mathrm{mg} \mathrm{L}^{-1}\right)$ is the initial concentration, $\mathrm{C}_{e}\left(\mathrm{mg} \mathrm{L}^{-1}\right)$ is the equilibrium concentration, $\mathrm{V}(\mathrm{L})$ is the volume of the solution, and $\mathrm{m}$ is the mass of the adsorbent.

\section{Results and discussion}

\subsection{Characterization of the geopolymer}

\subsubsection{Quantitative X-ray diffraction (XRD)}

Table 1 and figure $\mathrm{S} 1$ (in supplementary files) present the XRD analyses of the zeolite and the three geopolymer samples prepared (G-10, G-17, and G-28) and cured for an additional 9, 16, 27 days at room temperature. The tuffs are mainly composed of mordenite, quartz, and calcite. For the geopolymer samples, the amount of amorphous, ill-crystallized, or non-crystallized phases increases with the curing time but decreases silica and mordenite. It seems that during the curing time, mordenite and quartz react with the alkaline activator to form an amorphous phase, mainly sodium aluminosilicate hydrate, as a result of geopolymerization reaction (Ruiz-Santaquiteria et al., 2013; Garcia-Lodeiro et al., 2015; Biel et al., 2020).

Table 1. XDR analysis for crystalline structures and amorphous content of zeolite and geopolymer samples at room temperature.

\begin{tabular}{|c|c|c|c|c|}
\hline XRD & $\begin{array}{c}\text { Quartz (Qz) } \\
(\%)\end{array}$ & $\begin{array}{c}\text { Mordenite } \\
(\%)\end{array}$ & $\begin{array}{c}\text { Calcite } \\
(\%)\end{array}$ & $\begin{array}{c}\text { Amorphous } \\
(\%)\end{array}$ \\
\hline Zeolite & 20.8 & 28.5 & 4.2 & 46.4 \\
\hline G-10 & 18.4 & 28.3 & 5.7 & 47.6 \\
\hline G-17 & 15.5 & 24.7 & 5 & 54.8 \\
\hline
\end{tabular}




\begin{tabular}{|l|l|l|l|l|}
\hline G-28 & 13.4 & 19.6 & 3.3 & 63.7 \\
\hline
\end{tabular}

\subsubsection{FTIR analyses}

Both zeolite and geopolymer samples have been analyzed in the wavenumber range from 4000 to $400 \mathrm{~cm}^{-1}$ (see Figure S2 in supplementary files). Different bands were identified: (i) The band located around $3460 \mathrm{~cm}^{-1}$ is attributed to an asymmetric extension of $\mathrm{H}-\mathrm{O}$. Likewise, (ii) the band around $1636 \mathrm{~cm}^{-1}$ is due to $\mathrm{H}-\mathrm{OH}$ bending and the adsorption of hydroxyl groups by excess alkali and water, respectively. Similarly, (iii) the vibration around $1040 \mathrm{~cm}^{-1}$ is credited to asymmetric extensions between Si-O$\mathrm{Si}$ or Al-O-Si. Finally, (iv) the peaks around 1430 and $876 \mathrm{~cm}^{-1}$ are attributed to carbonate formed by exposure to atmospheric air (Singhal et al., 2017; Yan et al., 2019). The other peaks below $798 \mathrm{~cm}^{-1}$ are endorsed to different stretching modes, ring vibration of the structural network, and bending between $\mathrm{Si}-\mathrm{O}$ and $\mathrm{Al}-\mathrm{O}$ bonds.

\subsubsection{Thermogravimetric analysis and differential scanning calorimetry (TGA- DSC)}

Table 2 and figure S3 (in supplementary files) indicate the zeolite's thermogravimetric analysis and the geopolymers studied in this study. Between $0-110^{\circ} \mathrm{C}$, there is a significant loss of mass due to solid residual $\mathrm{NaOH}$, a possible increase in the material's porosity, which is evidenced in a more significant loss of surface water. In the range between $550-750{ }^{\circ} \mathrm{C}$, the zeolite losses more mass compared to the geopolymer. This can be explained by the fact that the zeolite contains $\mathrm{CaCO}_{3}$, whose decomposition point is around $700-750^{\circ} \mathrm{C}$, while the geopolymer, containing $\mathrm{NaOH}$ in excess, replaces $\mathrm{Ca}$ for $\mathrm{Na}$, forming $\mathrm{Na}_{2} \mathrm{CO}_{3}$, which decompose in $\mathrm{CO}_{2}$ and $\mathrm{Na}_{2} \mathrm{O}$ at temperatures above $1000^{\circ} \mathrm{C}$. Considering ca. $14-15 \%$ total mass loss, it is evident that geopolymer samples are highly thermally stable. Due to this reality, this kind of materials can be used as at high temperatures for different applications (Khan et al., 2015). 
Table 2. TGA-DSC analysis (up to $1000^{\circ} \mathrm{C}$ ) for zeolite and geopolymer samples

\begin{tabular}{|l|c|c|c|c|c|c|c|}
\hline \multicolumn{7}{|c|}{ Sample } & \multicolumn{7}{c|}{ Mass loss (\%) } & $\begin{array}{c}\text { Total } \\
\text { mass } \\
\text { loss } \\
(\%)\end{array}$ \\
\hline Temperature $\left(^{\circ} \mathrm{C}\right)$ & $0-110$ & $110-200$ & $200-320$ & $320-550$ & $550-750$ & $750-990$ & \\
\hline Zeolite & 3.77 & 1.72 & 1.08 & 1.52 & 7.48 & 0.41 & 15.98 \\
\hline Temperature ( $\left.{ }^{\circ} \mathbf{C}\right)$ & $0-150$ & $150-212$ & $212-350$ & $350-600$ & $600-700$ & $700-750$ & \\
\hline G- 10 & 8.39 & 1.96 & 2.01 & 1.21 & 0.7 & 0.1 & 14.37 \\
\hline G- 17 & 8.09 & 1.96 & 1.97 & 1.66 & 0.82 & 0.07 & 14.57 \\
\hline G- 28 & 7.26 & 2.12 & 2.15 & 1.73 & 0.81 & 0.05 & 14.12 \\
\hline
\end{tabular}

\subsubsection{Scanning electron microscopy and energy dispersive spectroscopy (SEM-EDS)}

As seen in figure 1, there is an increase in sodium percentage in the geopolymer sample analyzed. This change is attributed to $\mathrm{NaOH}$ and sodium silicate used for geopolymer synthesis. On the other hand, the increase in carbon percentage is due to the uptake of $\mathrm{CO}_{2}$ (carbonation) with unreacted and excess alkaline activators. Semi-quantitative elemental analysis by SEM-EDS of both raw material zeolite and all corresponding synthetized geopolymers are presented in figure 1. 


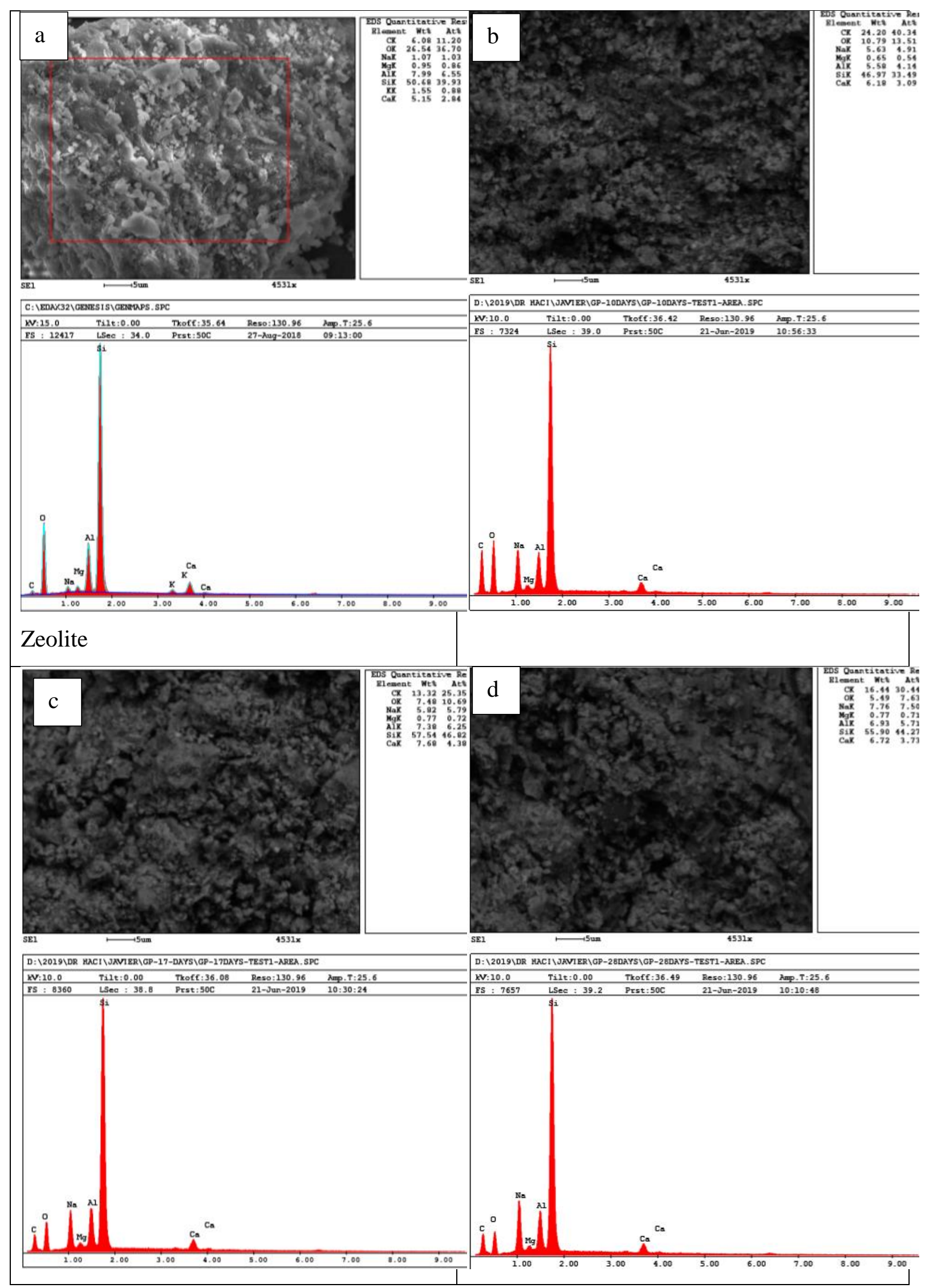

Figure 1. SEM-EDS images for a) zeolite, b) geopolymer cured for 9 days, c) geopolymer cured for 16 days, and d) geopolymer cured for 27 days. 
As seen in SEM-EDS images (see figure 1), it is clear that there is an increase in C and $\mathrm{Na}$ elements attributed to the formation of carbonates and activators used $\mathrm{NaOH}$ and sodium silicate, respectively (Baykara et al., 2020).

Figure 2 shows the microstructure of natural zeolite and geopolymer synthesized.
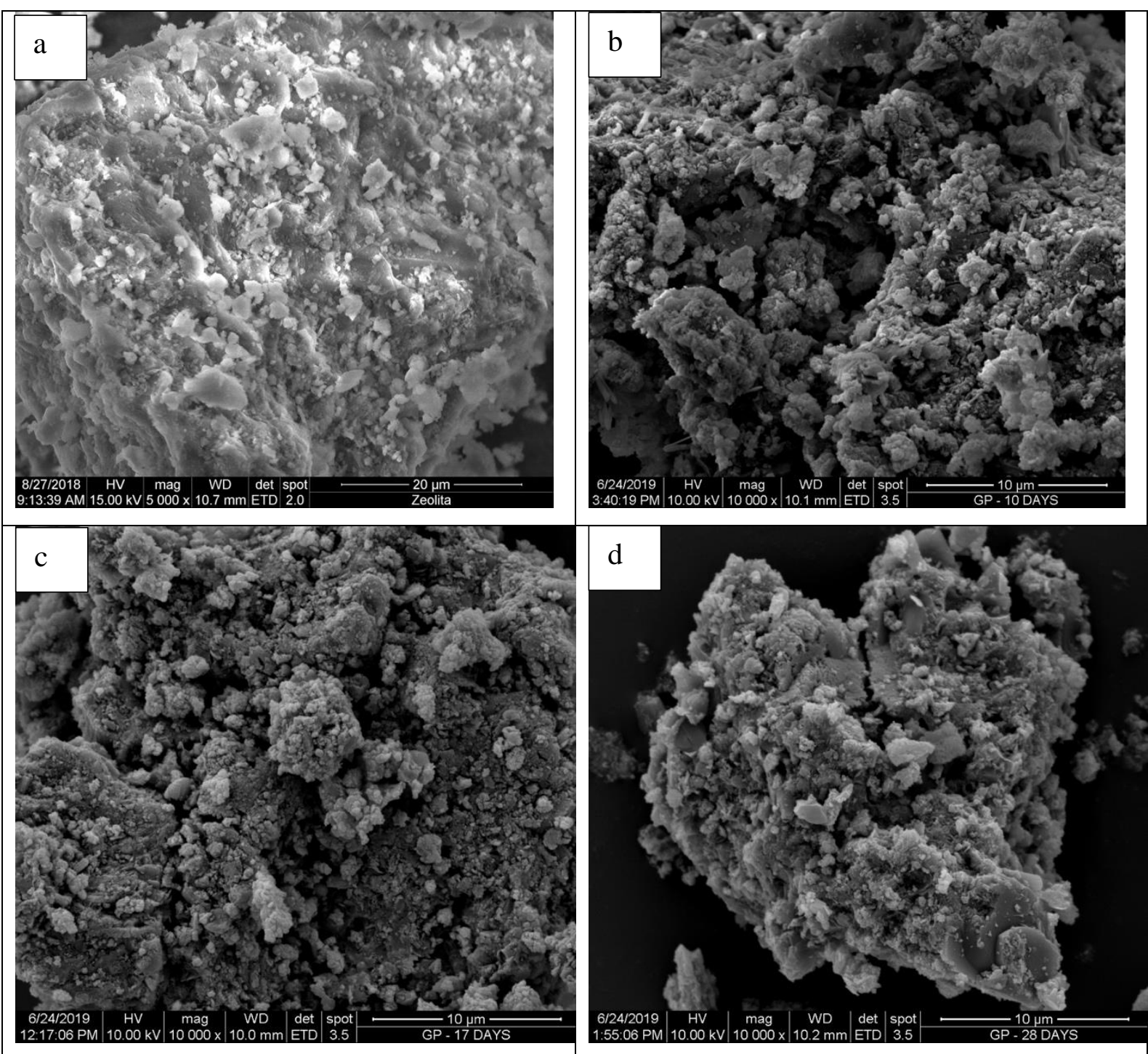

Figure 2. SEM micrographs a) zeolite, b) geopolymer cured for 9 days, c) geopolymer cured for 16 days, and d) geopolymer cured for 27 days.

Micrographs demonstrate that especially geopolymer samples have porous structures, which allows them to be used as adsorbents for copper removal from wastewater (Cheng et al., 2012; Duan et al., 2016). 


\subsection{Geopolymer compressive strength tests}

Table 3 shows the compressive strength of the geopolymers developed for this study. Additionally, the stress and strain curve of geopolymer samples' compressive strength tests can be seen in figure S4 (in supplementary files). There is a direct relationship between the curing time and the mechanical properties. Thus, the longer the curing time, the higher the compressive strength obtained. The geopolymer structure's hardening behavior suggests transforming mordenite and calcite into a load-bearing material as time increases. Several studies reported the highest curing days for different compressive strength tests and temperatures: 28 days $\left(15.84 \mathrm{MPa}\right.$ and $50^{\circ} \mathrm{C}$ ) for a mixture of metakaolin, zeolite and cork residues (Sudagar et al., 2018); 14 days $\left(9.95 \mathrm{MPa}\right.$ and $50^{\circ} \mathrm{C}$ ) for a mixture containing metakaolin and zeolite (Andrejkovičová et al., 2016); 28 days (10 MPa at $60^{\circ} \mathrm{C}$ ) for an Ecuadorian zeolite-based geopolymer (Baykara et al., 2017) and 14 days (about $19 \mathrm{MPa}$ at $80^{\circ} \mathrm{C}$ ) for other type of Ecuadorian zeolite-based geopolymer (Ulloa et al., 2018).

Table 3. Compressive strengths geopolymer blocks

\begin{tabular}{|l|c|c|}
\hline Block & Curing Time (Day) & Maximum compressive strength (MPa) \\
\hline B-3 & 10 & 17.06 \\
\hline C-3 & 17 & 21.35 \\
\hline D-3 & 28 & 26.86 \\
\hline
\end{tabular}

\subsection{Kinetic results}

Figure 3 shows the variation of $\mathrm{Cu}^{2+}$ concentration plotted versus time. It can be seen a step-down in $\mathrm{Cu}^{2+}$ concentration within the first minute of contact of the geopolymer with the $\mathrm{Cu}^{2+}$ solution, dropping from 94.7 to $28.32 \mathrm{ppm}$. Then, a slight decrease begins for 2 hours, reaching $5.02 \mathrm{ppm}$ of $\mathrm{Cu}^{2+}$ in the solution. The kinetic model was determined by the linearization approach using equations 3 to 5 for pseudo-first-order, pseudo-second-order, and Elovich, respectively (figure 4-6). The results obtained can be seen in table 4 .

$$
q_{t}=q_{e}\left(1-e^{-k_{1} t}\right)
$$




$$
\begin{aligned}
q_{t} & =\frac{q_{e}^{2} k_{2} t}{1+q_{e} k_{2} t} \\
q_{t} & =\frac{1}{\beta} \ln \left(v_{o} \beta\right)+\frac{1}{\beta} \ln (t)
\end{aligned}
$$

Where $\mathrm{q}_{\mathrm{e}}$ is the adsorption capacity at equilibrium, $\mathrm{q}_{\mathrm{t}}$ is the adsorption capacity until $\mathrm{t}$, $\mathrm{k}_{1}$ is the pseudo-first-order constant, $\mathrm{k}_{2}$ is the pseudo-second-order constant, $\beta$ is the desorption constant, and $\mathrm{v}_{\mathrm{o}}\left(\mathrm{mg} \mathrm{g}^{-1} \mathrm{t}^{-1}\right)$ is the initial adsorption rate.

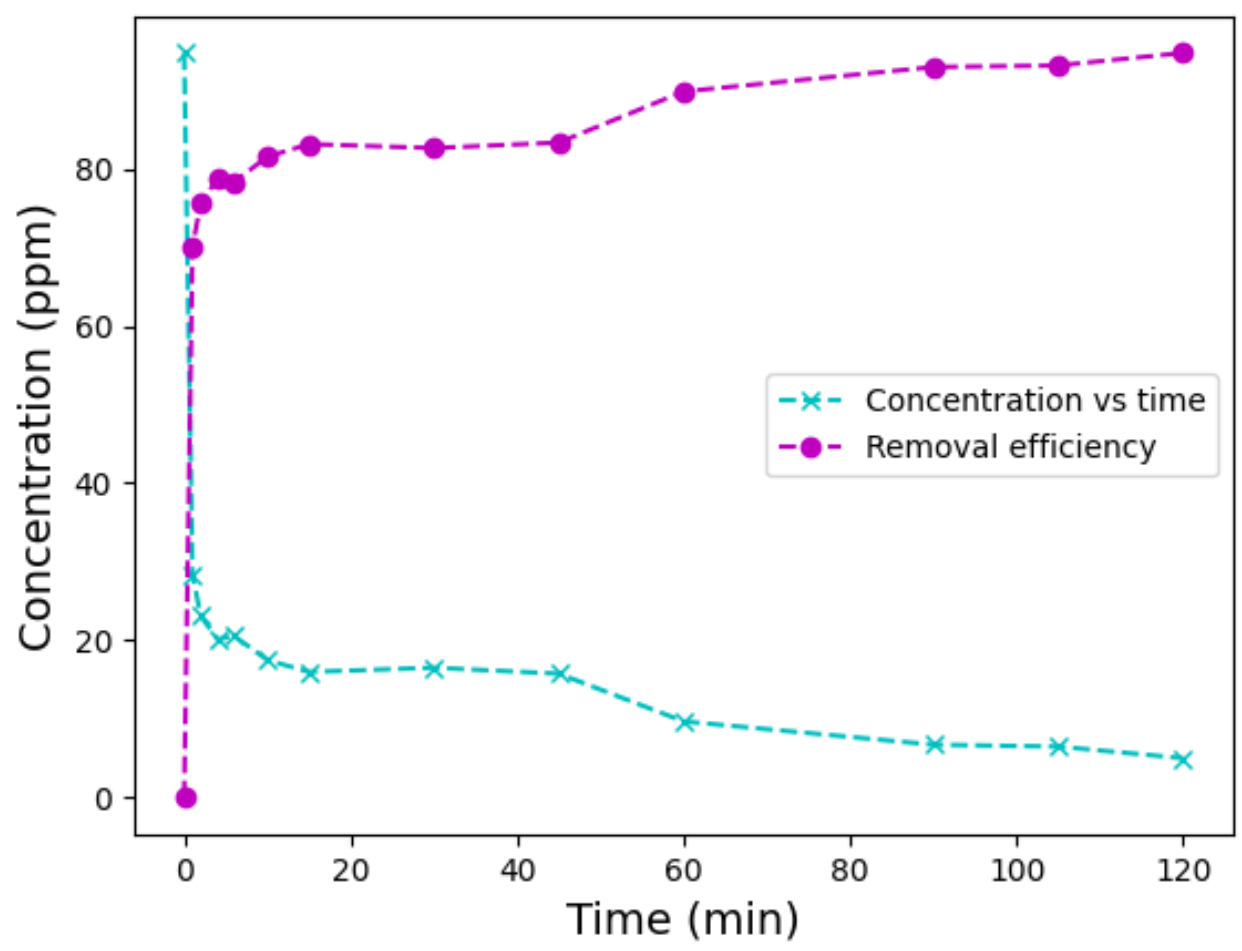

Figure 3. Change of $\mathrm{Cu}^{2+}$ concentration and geopolymer percentage of removal versus $\mathrm{Cu}^{2+}$ initial concentration as a function of time: 94.7 ppm; period: 120 minutes; batch constant temperature: $25^{\circ} \mathrm{C}$.

When comparing figures 3 to 5, it can be asserted that the adsorption process is better described by the pseudo-second-order equation rather than the pseudo-first-order equation, based on the linear coefficient of determination $\left(R^{2}\right)$. 


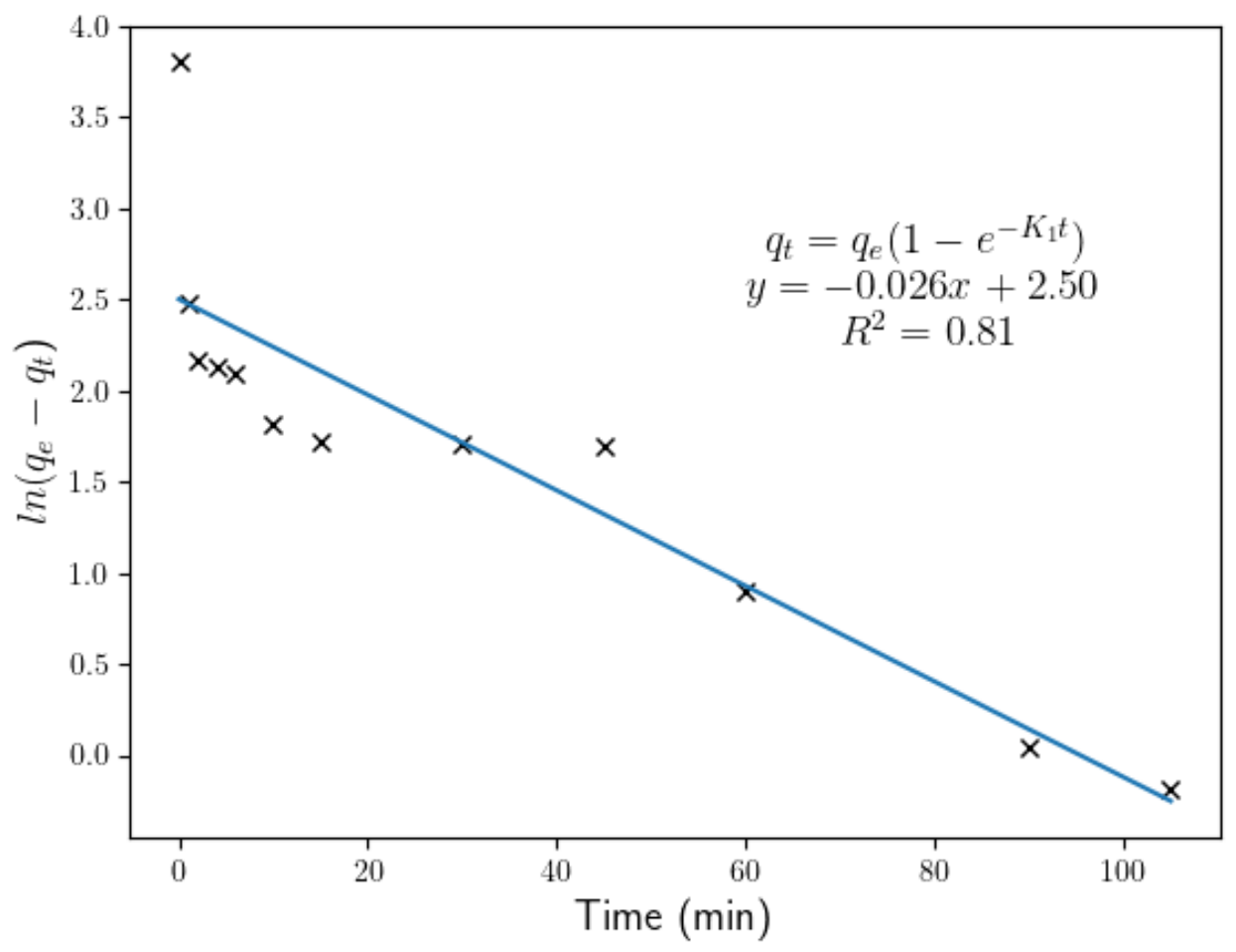

Figure 4. Kinetic result of the pseudo-first-order model in $\mathrm{Cu}^{2+}$ adsorption

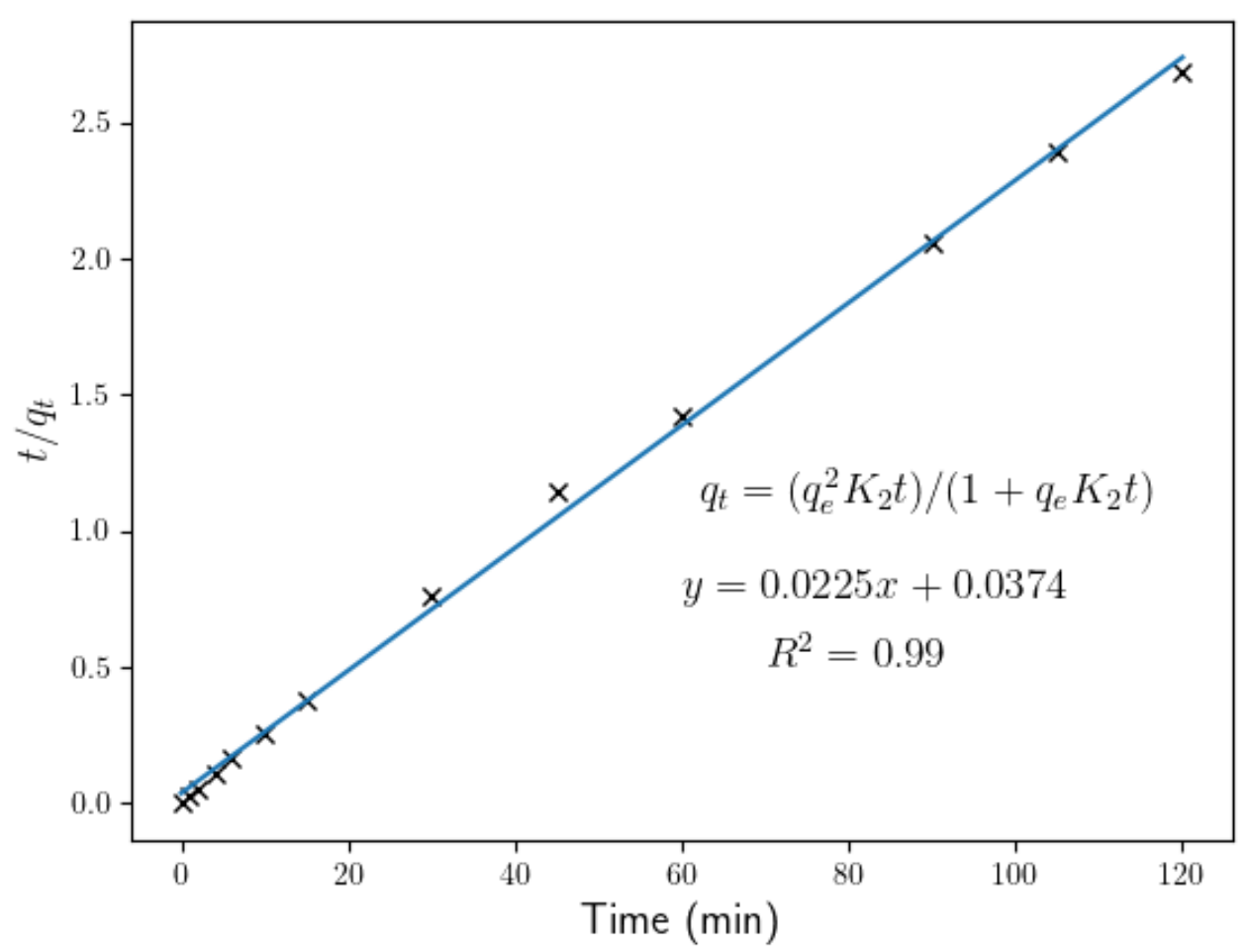

Figure 5. Kinetic result of the pseudosecond-orderr model in $\mathrm{Cu}^{2+}$ adsorption 
It must be said that each known theoretical ground of pseudo-second-order equation is based on fundamental theories of surface reactions (Azizian, 2004). Therefore, this equation is more accurate as the system reaches equilibrium and diffusion-driven sorption kinetics in non-equilibrium processes (Plazinski et al., 2013). This equation is linked to the direct adsorption/desorption process controlling the overall rate of sorption kinetics (Plazinski et al., 2009), which is the present study's case.

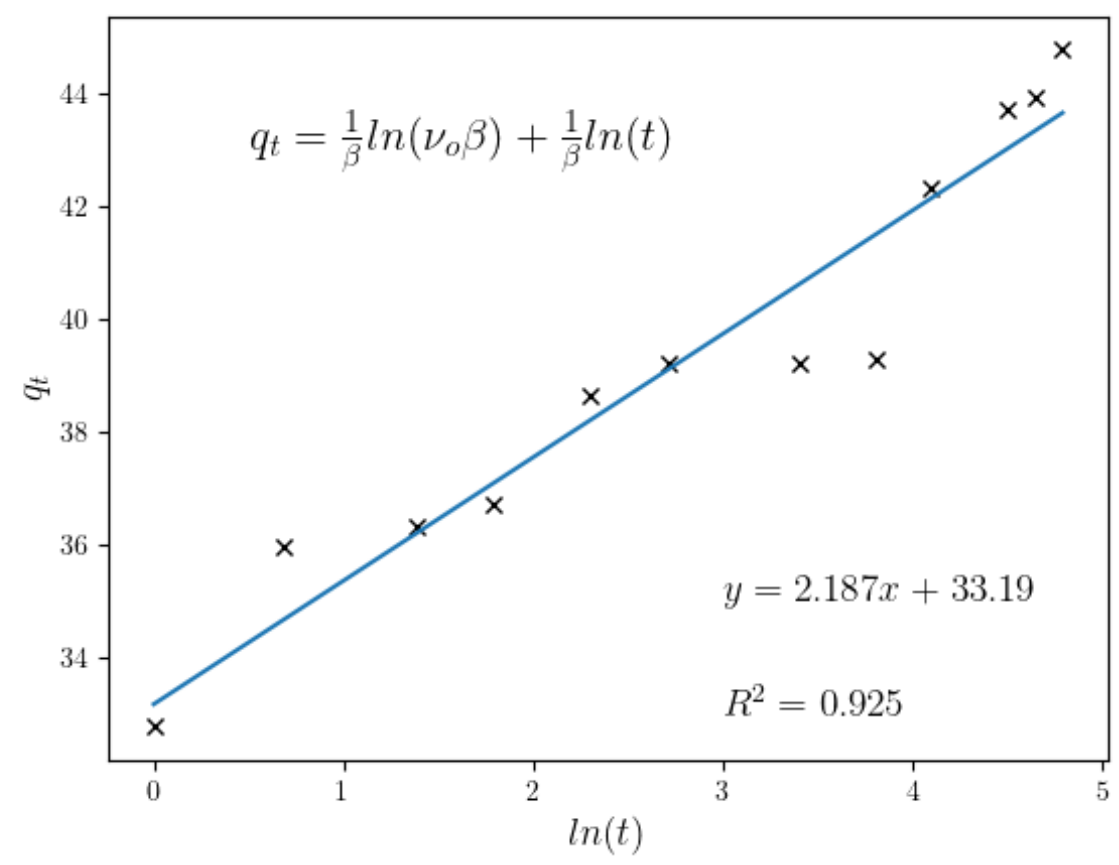

Figure 6. Kinetic result of the Elovich model in $\mathrm{Cu}^{2+}$ adsorption

Table 4. Kinetic parameters for adsorption of $\mathrm{Cu}^{2+}$ on geopolymer. $\mathrm{Cu}^{2+}$ initial concentration: $94.7 \mathrm{ppm}$. Experimental period: 120 minutes, batch temperature: $25^{\circ} \mathrm{C}$.

\begin{tabular}{|c|c|r|c|}
\hline Model & Parameters & Value & Unit \\
\hline \multirow{3}{*}{ Pseudo first order } & $\mathrm{R}^{2}$ & 0.81 & \\
\cline { 2 - 4 } & $\mathrm{K}_{1}$ & 0.0262 & $\mathrm{~min}^{-1}$ \\
\cline { 2 - 4 } & $\mathrm{q}_{\mathrm{e}}$ & 12.21 & $\mathrm{mg} \mathrm{g}^{-1}$ \\
\hline \multirow{3}{*}{ Pseudo second order } & $\mathrm{R}^{2}$ & 0.99 & \\
\cline { 2 - 4 } & $\mathrm{K}_{2}$ & 0.0135 & $\mathrm{~g} \mathrm{mg}^{-1} \mathrm{~min}^{-1}$ \\
\cline { 2 - 4 } & $\mathrm{qe}_{\mathrm{e}}$ & 44.44 & $\mathrm{mg} \mathrm{g}^{-1}$ \\
\hline Elovich & $\mathrm{R}^{2}$ & 0.925 & \\
\hline
\end{tabular}




\begin{tabular}{|l|c|r|r|} 
& $\beta$ & 0.4571 & $\mathrm{~g} \mathrm{mg}^{-1}$ \\
\cline { 2 - 4 } & Vo & 8517998.22 & $\mathrm{mg} \mathrm{g}^{-1} \mathrm{~min}^{-1}$ \\
\hline
\end{tabular}

Other models, such as the Weber-Morris model (equation 6), are based on intraparticle diffusion, which explains that the ion exchange phenomenon is proportional to the square root of time.

$$
q_{t}=K_{i d} t^{0.5}+C
$$

$K_{\text {id }}$ is the intraparticle diffusion ratio, and $C$ is a constant model (Luukkonen et al., 2016b, 2016a). This model can explain whether the adsorption mechanism occurs on the surface or in the geopolymer's pores. In Figure 7, a multilinearity is observed in the diffusion model, indicating a slow ingress of ions into the pores (sodium ion exchange), which appears to be slow, as reflected by the slope. The experimental results brought about for stage $K_{\text {id: }} 0,9863$ and for $C: 34,116\left(R^{2}: 0,9199\right)$ (see figure 7$)$. Nevertheless, it can be asserted that the Weber-Morris plot for this study, indicates that the sorption process consists of several phases. Furthermore, the plots do not pass through the origin, showing that the rate-limiting step is not the pore diffusion (i.e., intraparticle) but the film diffusion (i.e., boundary-layer). Therefore, the first phases of sorption are related to the attachment to the most readily available surface sites, whereas the latter phases involve the slow diffusion of adsorbate from the surface to the inner pores (Luukkonen et al., 2016a). 


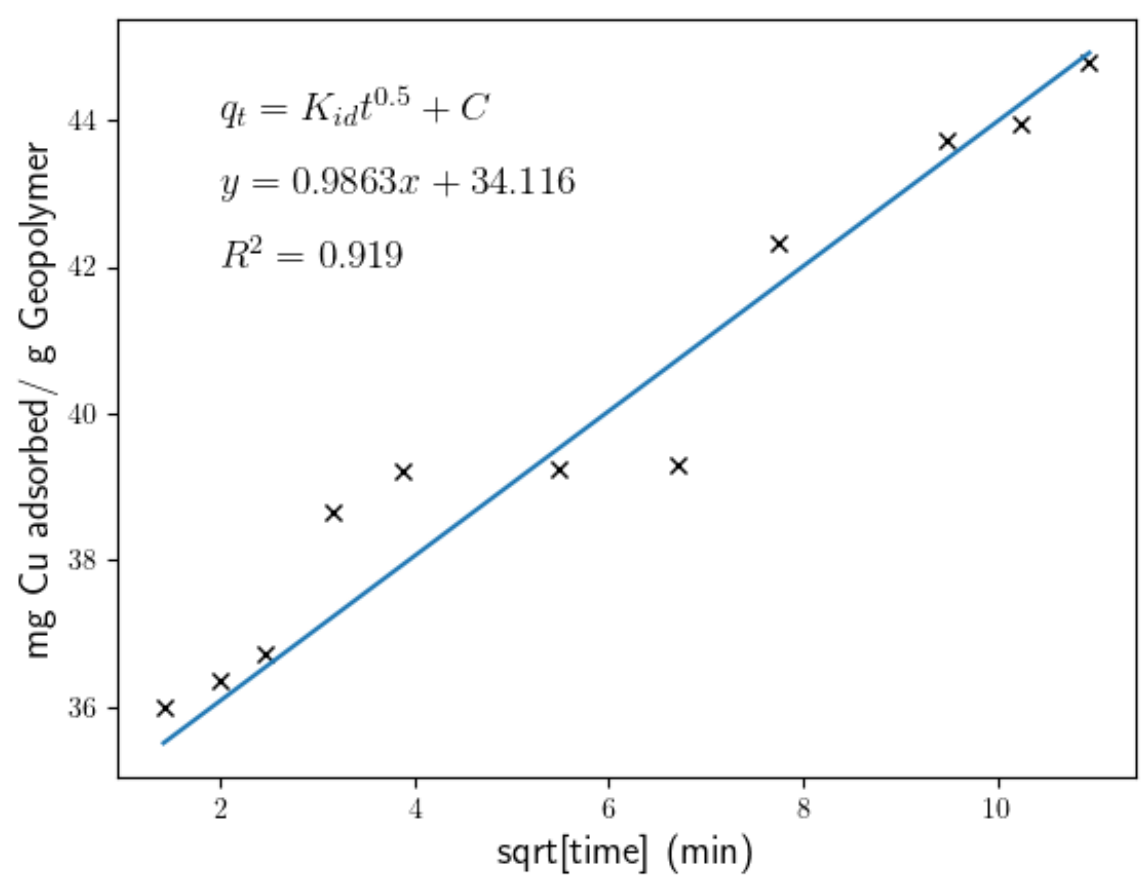

Figure 7. Kinetic result of the Weber-Morris model (intraparticle diffusion model).

\subsection{Adsorption isotherms}

The results were fitted to the linearized Langmuir and Freundlich models (Equations 78 and 9-10, respectively) to clarify the adsorption mechanism.

$$
\begin{aligned}
& q_{e}=\frac{k_{L} C_{e} q_{m}}{1+C_{e} k_{L}} \\
& \frac{C_{e}}{q_{e}}=\frac{1}{K_{L} q_{m}}+\frac{C_{e}}{q_{m}} \\
& q_{e}=K_{F} C_{e}^{\frac{1}{n}} \\
& \log \left(q_{e}\right)=\log \left(K_{F}\right)+\frac{1}{n} \log \left(C_{e}\right)
\end{aligned}
$$

Where $\mathrm{q}_{\mathrm{m}}$ is the maximum adsorption capacity for the adsorption monolayer formation, $\mathrm{n}$ is the adsorption intensity $\left(0<1 / 1\right.$ for favorable adsorption); $\mathrm{K}_{\mathrm{L}}\left(\mathrm{L} \mathrm{mg}^{-1}\right)$, and $\mathrm{K}_{\mathrm{F}}(\mathrm{mg} \mathrm{g}$ $\left.{ }^{1}\left(\mathrm{~L} \mathrm{mg}^{-1}\right)^{1 / \mathrm{n}}\right)$ are the constants of Langmuir and Freundlich respectively.

The highest and lowest removal efficiencies (from initial concentrations of 20.4, 69.9, 100.3, 129.6 y 160.7 ppm, as measured in the atomic adsorption equipment), were $97.7 \%$ and $67.76 \%$ for 69.9 and 160.7 ppm, the latter suggesting saturation condition 
of the active sites of the geopolymer. Figure 9 presents Freundlich model isotherm. It was found a low correlation value of 0.636 . However, for the Langmuir model (see figure 8 ), the correlation value was 0.995 , implying a possible formation of monolayers on the adsorbent surface, with a maximum adsorption capacity of $52.63 \mathrm{mg} \mathrm{g}^{-1}$ and an isotherm constant $\left(\mathrm{K}_{\mathrm{i}}\right)$ of 0.42 .

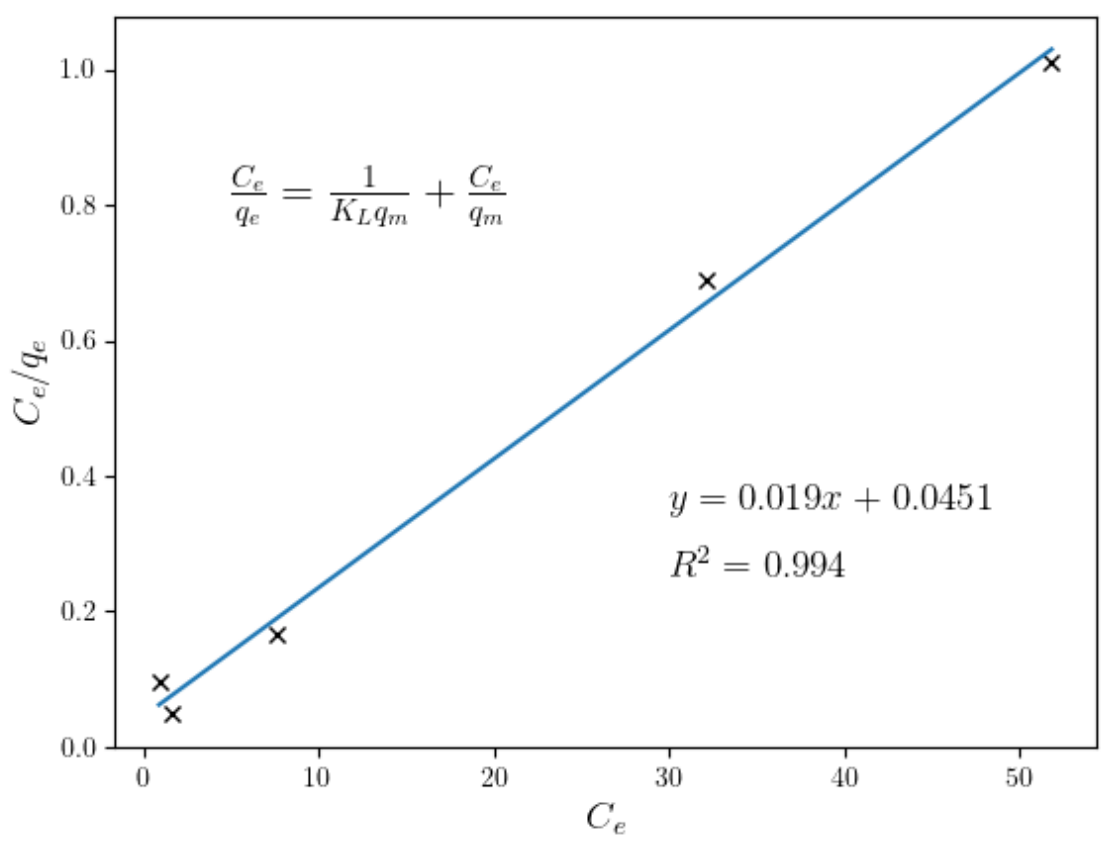

Figure 8. Results of the Langmuir isotherm model. Constant temperature, batch, $2 \mathrm{~g}$ L-1 dose. 


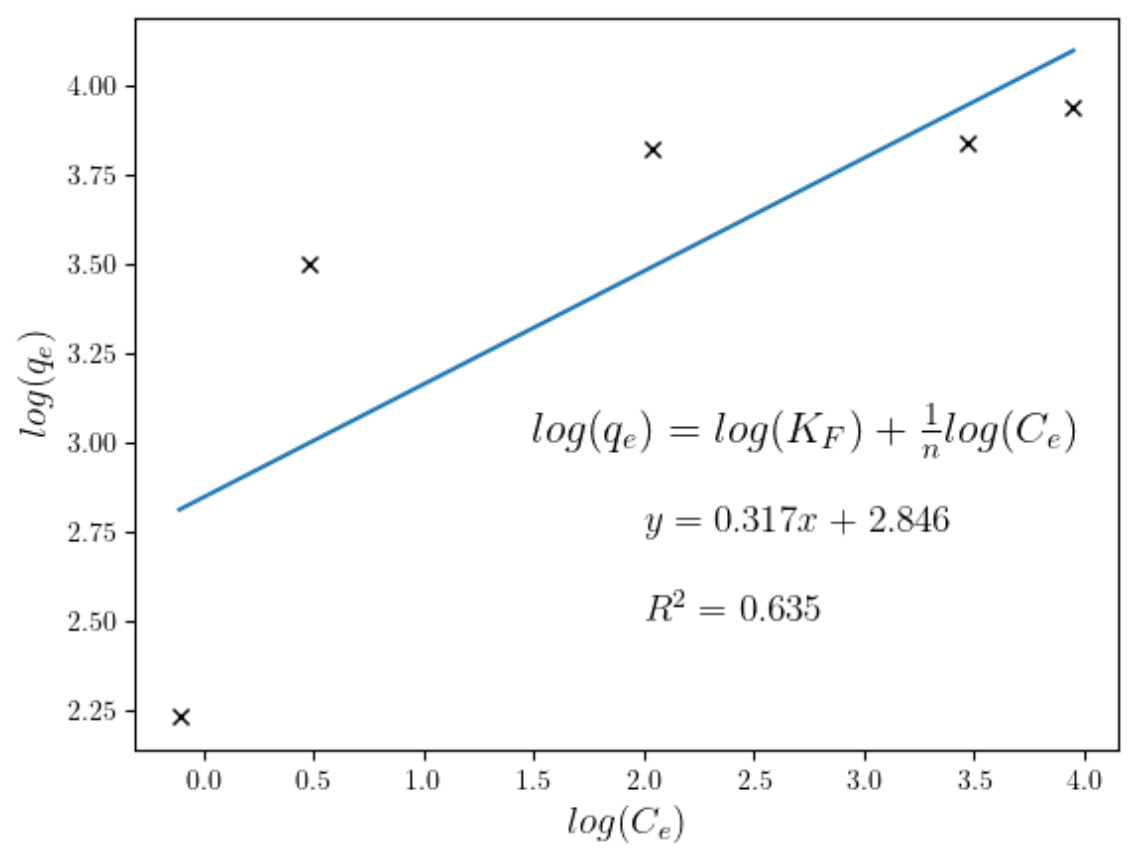

Figure 9. Results of the Freundlich isotherm model. Conditions: Constant temperature, batch, $2 \mathrm{~g}$ L-1 dose. 
Figure 10 represents a comparison of experimental and theoretical Langmuir isotherm model. This result is consistent with the studies of Signhal et al. (Singhal et al., 2017) and Cheng et al. (Cheng et al., 2012) which demonstrates that using porous geopolymers for copper removal from water follows the Langmuir model.

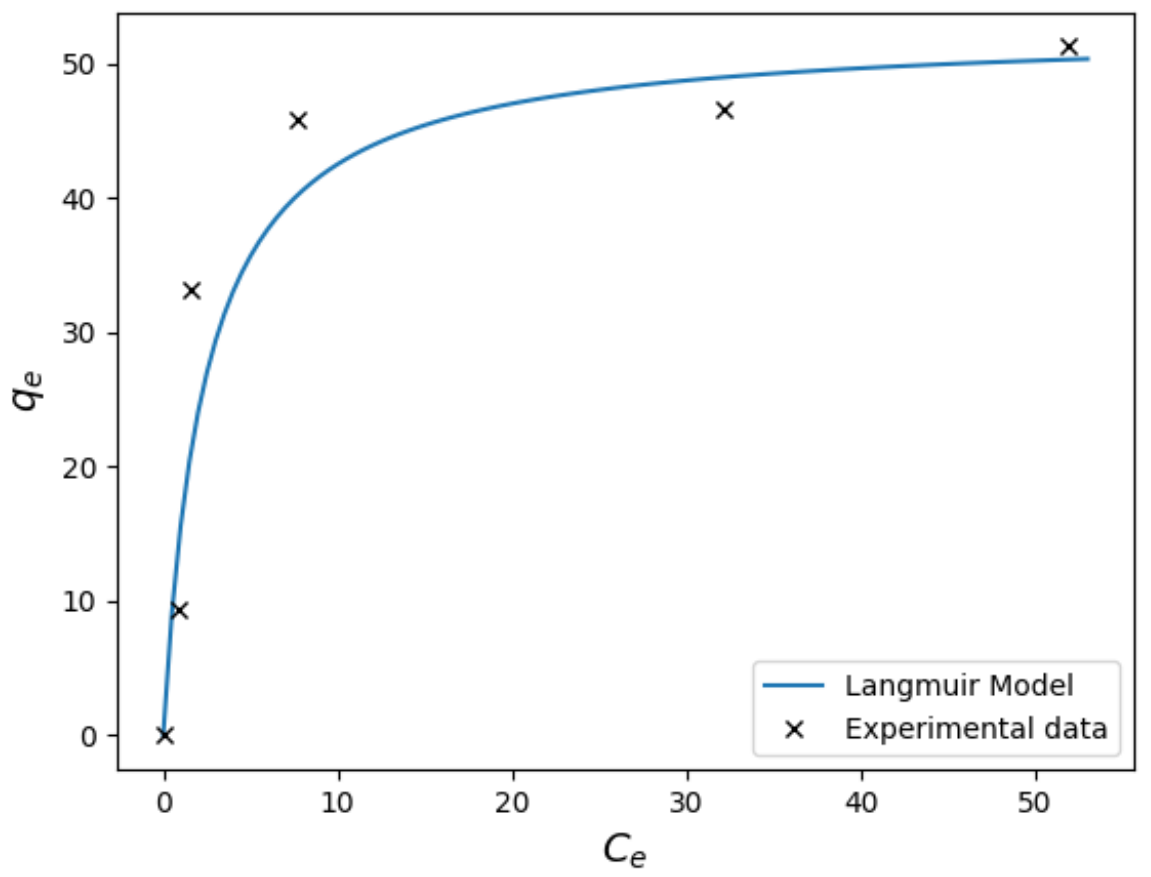

Figure 10. Comparison between experimental data and the Langmuir isotherm

Table 5 demonstrates the compared the adsorption capacity values for $\mathrm{Cu}^{2+}$ adsorption of various studies. Considering adsorption capacity values, the present study shows a competitive adsorption capacity relatively close to that reported by Sudagar et al., (2018), using metakaolin-based geopolymer spheres.

Table 5. Comparison of copper adsorption capacity of the geopolymer under study with other studies

\begin{tabular}{|l|c|c|}
\hline Material & $\begin{array}{c}\text { Adsorption } \\
\text { Capacity } \\
\left(\mathrm{mg} \mathrm{g}^{-1}\right)\end{array}$ & Reference \\
\hline Metakaolin based geopolymer & 40.9 & (Cheng et al., 2012) \\
\hline
\end{tabular}




\begin{tabular}{|l|c|c|}
\hline Metakaolin based geopolymer & 15 & (López et al., 2014) \\
\hline Metakaolin based geopolymer & 44.73 & (Andrejkovičová et al., 2016) \\
\hline Metakaolin based geopolymer & 40 & (Singhal et al., 2017) \\
\hline Metakaolin based geopolymer spheres & 35 & (Tang et al., 2015) \\
\hline Metakaolin-zeolite based geopolymer & 55.92 & (Sudagar et al., 2018) \\
\hline Zeolite based geopolymer & 52.63 & Present study \\
\hline
\end{tabular}

\section{Conclusions}

This study aims to synthesize Ecuadorian natural zeolite-based geopolymers for a potential industrial application to remove copper from aqueous media. The results indicated that the prepared geopolymer samples with a particle size of less than $60 \mu \mathrm{m}$ are an efficient adsorbent for copper removal compared to similar studies.

Kinetic study reveals that the $\mathrm{Cu}^{2+}$ adsorption on the geopolymers follows a pseudosecond-order linear behavior. Consequently, based on the linear coefficient of determination $\left(R^{2}\right)$, the present study is in good agreement with a sorption process of copper on the zeolite-based geopolymer from a very high concentration. Simultaneously, it obeys the pseudo-second-order kinetics model at the lower initial concentration of the adsorbate.

Adsorption isotherms calculation results fit perfectly with the Langmuir adsorption model. 


\section{References}

Al-Harahsheh, M.S., Al Zboon, K., Al-Makhadmeh, L., Hararah, M., Mahasneh, M., Al, K., Al-Makhadmeh, L., Hararah, M., Mahasneh, M., 2015. Fly ash based geopolymer for heavy metal removal : A case study on copper removal. Environ. Chem. Eng. 3, 1669-1677. https://doi.org/10.1016/j.jece.2015.06.005 Andrejkovicoá, S., Sudagar, A., Rocha, J., Patinha, C., Hajjaji, W., da Silva, E.F., Velosa, A., Rocha, F., 2016. The effect of natural zeolite on microstructure, mechanical and heavy metals adsorption properties of metakaolin based geopolymers. Appl. Clay Sci. 126, 141-152. https://doi.org/10.1016/j.clay.2016.03.009

Andrejkovičová, S., Sudagar, A., Rocha, J., Patinha, C., Hajjaji, W., Da Silva, E.F., Velosa, A., Rocha, F., 2016. The effect of natural zeolite on microstructure, mechanical and heavy metals adsorption properties of metakaolin based geopolymers. Appl. Clay Sci. 126, 141-152. https://doi.org/10.1016/j.clay.2016.03.009

Arnoult, M., Perronnet, M., Autef, A., Rossignol, S., 2018. How to control the geopolymer setting time with the alkaline silicate solution. J. Non. Cryst. Solids 495, 59-66. https://doi.org/10.1016/j.jnoncrysol.2018.02.036

Azizian, S., 2004. Kinetic models of sorption: a theoretical analysis. J. Colloid Interface Sci. 276, 47-52. https://doi.org/10.1016/j.jcis.2004.03.048

Barrie, E., Cappuyns, V., Vassilieva, E., Adriaens, R., Hollanders, S., Garcés, D., Paredes, C., Pontikes, Y., Elsen, J., Machiels, L., 2015. Potential of inorganic polymers (geopolymers) made of halloysite and volcanic glass for the immobilisation of tailings from gold extraction in Ecuador. Appl. Clay Sci. 109Ãfâ€šÃ, 95-106. https://doi.org/http://dx.doi.org/10.1016/j.clay.2015.02.025

Baykara, H., Cornejo, M.H., Espinoza, A., García, E., Ulloa, N., 2020. Preparation, characterization, and evaluation of compressive strength of polypropylene fiber reinforced geopolymer mortars. Heliyon 6, e03755. https://doi.org/10.1016/j.heliyon.2020.e03755

Baykara, H., Cornejo, M.H., Murillo, R., Gavilanes, A., Paredes, C., Elsen, J., 2017. Preparation, characterization and reaction kinetics of green cement: Ecuadorian natural mordenite-based geopolymers. Mater. Struct. 50, 188.

https://doi.org/10.1617/s11527-017-1057-z

Biel, O., Rożek, P., Florek, P., Mozgawa, W., Król, M., 2020. Alkaline Activation of 
Kaolin Group Minerals. Crystals 10, 268. https://doi.org/10.3390/cryst10040268 Cheng, T.W., Lee, M.L., Ko, M.S., Ueng, T.H., Yang, S.F., 2012. The heavy metal adsorption characteristics on metakaolin-based geopolymer. Appl. Clay Sci. 56, 90-96. https://doi.org/10.1016/j.clay.2011.11.027

Cristelo, N., Oliveira, M., Consoli, N.C., Palomo, Á., 2020. Recycling and Application of Mine Tailings in Alkali-Activated Cements and Mortars - Strength Development and Environmental Assessment. Appl. Sci. 10.

Duan, P., Yan, C., Zhou, W., Ren, D., 2016. Development of fly ash and iron ore tailing based porous geopolymer for removal of $\mathrm{Cu}(\mathrm{II})$ from wastewater. Ceram. Int. 42, 13507-13518. https://doi.org/10.1016/j.ceramint.2016.05.143

Garcia-Lodeiro, I., Cherfa, N., Zibouche, F., Fernandez-Jimenez, A., Palomo, A., 2015. The role of aluminium in alkali-activated bentonites. Mater. Struct. 48 , 585-597. https://doi.org/10.1617/s11527-014-0447-8

Khan, M.I., Min, T.K., Azizli, K., Sufian, S., Ullah, H., Man, Z., 2015. Effective removal of methylene blue from water using phosphoric acid based geopolymers: synthesis, characterizations and adsorption studies. RSC Adv. 5, 61410-61420. https://doi.org/10.1039/C5RA08255B

Kim, J.S., Yi, J., 2000. Selective removal of copper ions from multi-component aqueous solutions using modified silica impregnated with LIX 84. J. Chem. Technol. Biotechnol. 75, 359-362. https://doi.org/10.1002/(SICI)10974660(200005)75:5<359::AID-JCTB223>3.0.CO;2-M

López, F.J., Sugita, S., Tagaya, M., Kobayashi, T., 2014. Metakaolin-Based Geopolymers for Targeted Adsorbents to Heavy Metal Ion Separation. J. Mater. Sci. Chem. Eng. 02, 16-27. https://doi.org/10.4236/msce.2014.27002

Luukkonen, T., Runtti, H., Niskanen, M., Tolonen, E., 2016a. Simultaneous removal of $\mathrm{Ni}$ ( II ), As ( III ), and Sb ( III ) from spiked mine ef fl uent with metakaolin and blast-furnace-slag geopolymers. J. Environ. Manage. 166, 579-588. https://doi.org/10.1016/j.jenvman.2015.11.007

Luukkonen, T., Sarkkinen, M., Kemppainen, K., Rämö, J., Lassi, U., 2016b. Metakaolin geopolymer characterization and application for ammonium removal from model solutions and landfill leachate. Appl. Clay Sci. 119, 266-276. https://doi.org/10.1016/j.clay.2015.10.027

National Research Council (US) Committe on Copper in Drinking Water, 2000. Health Effects of Excess Copper, Copper in Drinking Water. 
Obenaus-Emler, R., Falah, M., Illikainen, M., 2020. Assessment of mine tailings as precursors for alkali-activated materials for on-site applications. Constr. Build. Mater. 246, 118470. https://doi.org/10.1016/j.conbuildmat.2020.118470

Plazinski, W., Dziuba, J., Rudzinski, W., 2013. Modeling of sorption kinetics: the pseudo-second order equation and the sorbate intraparticle diffusivity. Adsorption 19, 1055-1064. https://doi.org/10.1007/s10450-013-9529-0

Plazinski, W., Rudzinski, W., Plazinska, A., 2009. Theoretical models of sorption kinetics including a surface reaction mechanism: A review. Adv. Colloid Interface Sci. 152, 2-13. https://doi.org/10.1016/j.cis.2009.07.009

Ruiz-Santaquiteria, C., Fernández-Jiménez, A., Skibsted, J., Palomo, A., 2013. Clay reactivity: Production of alkali activated cements. Appl. Clay Sci. 73, 11-16. https://doi.org/http://dx.doi.org/10.1016/j.clay.2012.10.012

Sen Gupta, S., Bhattacharyya, K.G., 2014. Adsorption of metal ions by clays and inorganic solids. RSC Adv. 4, 28537-28586. https://doi.org/10.1039/C4RA03673E

Singhal, A., Gangwar, B.P., Gayathry, J.M., 2017. CTAB modified large surface area nanoporous geopolymer with high adsorption capacity for copper ion removal. Appl. Clay Sci. 150, 106-114. https://doi.org/10.1016/j.clay.2017.09.013

Sthiannopkao, S., Sreesai, S., 2009. Utilization of pulp and paper industrial wastes to remove heavy metals from metal finishing wastewater. J. Environ. Manage. 90, 3283-3289. https://doi.org/10.1016/j.jenvman.2009.05.006

Sudagar, A., Andrejkovičová, S., Patinha, C., Velosa, A., McAdam, A., da Silva, E.F., Rocha, F., 2018. A novel study on the influence of cork waste residue on metakaolin-zeolite based geopolymers. Appl. Clay Sci. 152, 196-210. https://doi.org/10.1016/j.clay.2017.11.013

Tang, Q., Ge, Y. yuan, Wang, K. tuo, He, Y., Cui, X. min, 2015. Preparation and characterization of porous metakaolin-based inorganic polymer spheres as an adsorbent. Mater. Des. 88, 1244-1249. https://doi.org/10.1016/j.matdes.2015.09.126

Taylor, A.A., Tsuji, J.S., Garry, M.R., McArdle, M.E., Goodfellow, W.L., Adams, W.J., Menzie, C.A., 2020. Critical Review of Exposure and Effects: Implications for Setting Regulatory Health Criteria for Ingested Copper. Environ. Manage. 65, 131-159. https://doi.org/10.1007/s00267-019-01234-y

Ulloa, N.A., Baykara, H., Cornejo, M.H., Rigail, A., Paredes, C., Villalba, J.L., 2018. 
Application-oriented mix design optimization and characterization of zeolitebased geopolymer mortars. Constr. Build. Mater. 174, 138-149. https://doi.org/10.1016/j.conbuildmat.2018.04.101

Wang, S., Li, L., Zhu, Z.H., 2007. Solid-state conversion of fly ash to effective adsorbents for Cu removal from wastewater. J. Hazard. Mater. 139, 254-259. https://doi.org/10.1016/j.jhazmat.2006.06.018

Yan, S., Zhang, F., Wang, L., Rong, Y., He, P., Jia, D., Yang, J., 2019. A green and low-cost hollow gangue microsphere/geopolymer adsorbent for the effective removal of heavy metals from wastewaters. J. Environ. Manage. 246, 174-183. https://doi.org/10.1016/j.jenvman.2019.05.120

Yousef, R.I., El-Eswed, B., Alshaaer, M., Khalili, F., Khoury, H., 2009. The influence of using Jordanian natural zeolite on the adsorption, physical, and mechanical properties of geopolymers products. J. Hazard. Mater. 165, 379-387. https://doi.org/10.1016/j.jhazmat.2008.10.004 